OPEN ACCESS

Edited by:

Andrea Guido Oreste Manetti, GlaxoSmithKline, United Kingdom

Reviewed by:

Dirk Schlüter,

Otto-von-Guericke Universität Magdeburg, Germany

Dinesh Sriramulu,

Shres Consultancy, India

*Correspondence:

Anne Breitrück

anne.breitrueck@izi.fraunhofer.de

Specialty section:

This article was submitted to

Infectious Diseases,

a section of the journal

Frontiers in Microbiology

Received: 28 November 2017

Accepted: 19 March 2018

Published: 10 April 2018

Citation:

Schäffler H and Breitrück A (2018) Clostridium difficile - From

Colonization to Infection

Front. Microbiol. 9:646.

doi: 10.3389/fmicb.2018.00646

\section{Clostridium difficile - From Colonization to Infection}

\author{
Holger Schäffler ${ }^{1}$ and Anne Breitrück ${ }^{2,3 *}$ \\ ${ }^{1}$ Division of Gastroenterology, Department of Medicine II, University of Rostock, Rostock, Germany, ${ }^{2}$ Extracorporeal \\ Immunomodulation Unit, Fraunhofer Institute for Cell Therapy and Immunology, Rostock, Germany, ${ }^{3}$ Institute of Medical \\ Microbiology, Virology and Hygiene, University of Rostock, Rostock, Germany
}

Clostridium difficile is the most frequent cause of nosocomial antibiotic-associated diarrhea. The incidence of $C$. difficile infection (CDI) has been rising worldwide with subsequent increases in morbidity, mortality, and health care costs. Asymptomatic colonization with $C$. difficile is common and a high prevalence has been found in specific cohorts, e.g., hospitalized patients, adults in nursing homes and in infants. However, the risk of infection with $C$. difficile differs significantly between these cohorts. While CDI is a clear indication for therapy, colonization with $C$. difficile is not believed to be a direct precursor for $\mathrm{CDI}$ and therefore does not require treatment. Antibiotic therapy causes alterations of the intestinal microbial composition, enabling $C$. difficile colonization and consecutive toxin production leading to disruption of the colonic epithelial cells. Clinical symptoms of CDI range from mild diarrhea to potentially life-threatening conditions like pseudomembranous colitis or toxic megacolon. While antibiotics are still the treatment of choice for $\mathrm{CDI}$, new therapies have emerged in recent years such as antibodies against $C$. difficile toxin B and fecal microbial transfer (FMT). This specific therapy for $\mathrm{CDI}$ underscores the role of the indigenous bacterial composition in the prevention of the disease in healthy individuals and its role in the pathogenesis after alteration by antibiotic treatment. In addition to the pathogenesis of CDI, this review focuses on the colonization of $C$. difficile in the human gut and factors promoting $\mathrm{CDI}$.

Keywords: Clostridium difficile, microbiota, Clostridium difficile infection, CDI, asymptomatic colonization

\section{INTRODUCTION}

Clostridium difficile was first described as part of the intestinal bacterial composition in newborns in 1935 (Hall and O'Toole, 1935). In the 1970s, C. difficile was identified as the causative agent for pseudomembranous colitis following antibiotic therapy. The pathogenic potential of this strain was proven to fulfill the Koch's postulates (Bartlett et al., 1977) underscoring its role in the development of CDI. Recently, a dramatic increase in the incidence as well as in the mortality of CDI could be observed worldwide (Ananthakrishnan, 2011; Lo Vecchio and Zacur, 2012; Tattevin et al., 2013).

The clinical spectrum of $C$. difficile ranges from asymptomatic colonization, mild and selflimiting disease to a severe, life-threatening pseudomembranous colitis, toxic megacolon, sepsis and death (Gerding et al., 1995; Rupnik et al., 2009). CDI is defined when there is the presence of symptomatic diarrhea defined by three or more unformed stools per $24 \mathrm{~h}$ and at least

Abbreviations: C. difficile, Clostridium difficile; CDI, C. difficile infection; FMT, fecal microbiota transfer; Ig, immunoglobulin; TcdA, C. difficile toxin A; TcdB, C. difficle toxin B. 
one of the following criteria: a positive laboratory assay for C. difficile toxin $\mathrm{A}$ and/or $\mathrm{B}$ or toxin-producing $C$. difficile organism in a stool sample or pseudomembranous colitis or colonic histopathology characteristics of CDI revealed by endoscopy (Kuijper et al., 2006; Cohen et al., 2010). CDI is associated with an increased abundance of toxin-producing C. difficile strains, leading to high toxin concentrations within the colon resulting in inflammation and damage of the colonocytes (Ishida et al., 2004; Meyer et al., 2007; Carroll and Bartlett, 2011). Usually, the indigenous microbial communities provide a colonization resistance to $C$. difficile, which could also be proven in animal models (Wilson et al., 1981). However, a disruption of this microbial system can promote the development of CDI (Rea et al., 2012; Buffie et al., 2015).

While the clinical presentation of CDI is distinctive, C. difficile colonization without any symptoms, defined as asymptomatic colonization is common, especially in neonates (Ozaki et al., 2004; Jangi and Lamont, 2010). This review focuses on the role of $C$. difficile in asymptomatic colonization and CDI to better understand which factors might contribute to the progression and also prevention of the disease.

\section{MICROBIOLOGY}

C. difficile is a Gram-positive, anaerobic, spore-forming and toxin-producing bacillus, belonging to cluster XI the Clostridium genus and can be isolated from water, vegetables, hospital environment, and the intestines of humans and domesticated animals (Weese, 2010).

Different virulence factors are associated with the development of CDI. The most important virulence factor is the release of multiple toxins, namely large glycosylating exotoxins $A(\operatorname{Tcd} A)$ and $B(\operatorname{TcdB})$. These toxins lead to the characteristic clinical symptoms by binding to $C$. difficile toxin receptors on intestinal epithelial cells (Kelly and LaMont, 1998; Voth and Ballard, 2005; Pruitt and Lacy, 2012; Shen, 2012). Another toxin can be found in some C. difficile strains, especially the PCR ribotype 027, named binary toxin or C. difficile transferase, which is associated with a higher mortality rate in patients (Gerding et al., 2014). This ribotype 027 carries a deletion in tcdC, which is discussed to play a major role in its increased production of toxins (Warny et al., 2005; Curry et al., 2007; Dupuy et al., 2008). There are C. difficile strains which can synthesize $C$. difficile transferase in the absence of TcdA and TcdB (McFarland et al., 2007a). These toxins, which are encoded on the pathogenicity locus, are multi-domain toxins with glycosyltransferase activities, which transfer glycosyl residues to small Ras homologous GTPases and consecutively lead to a loss of the intestinal membrane integrity and to cell death (Schirmer and Aktories, 2004; Moore et al., 2013). As a consequence, inflammation of the colon occurs with massive fluid loss into the large intestine, clinically presenting as acute diarrhea (Voth and Ballard, 2005). While initially TcdA was suggested to play a more prominent role in the development of CDI compared to TcdB, this view was challenged by different other studies (Lyerly et al., 1985; Komatsu et al., 2003; Drudy et al., 2007; Lyras et al., 2009;
Steele et al., 2013). Colonization with C. difficile occurs by oral ingestion of spores from infected individuals or the environment (Jump et al., 2007; Gerding et al., 2008; Sarker and Paredes-Sabja, 2012). While C. difficile is an anaerobic organism, C. difficile spores can survive in aerobic environments for months or years (Rupnik et al., 2009). C. difficile spores are resistant to the gastric acid and can germinate into vegetative cells in the anaerobic conditions of the colon (Gil et al., 2017).

\section{EPIDEMIOLOGY OF CDI}

The worldwide incidence of CDI has been rising steadily since 2000, however, susceptibility to treatment decreased (McDonald et al., 2006; Vardakas et al., 2012; Bagdasarian et al., 2015). C. difficile was first reported to cause severe antibiotic-associated diarrhea and pseudomembranous colitis in the 1970s and has become the most common healthcare-associated infection, leading to about 500,000 cases and 29,000 deaths annually in the United States (Bartlett et al., 1978; Bartlett, 2006; Lessa et al., 2015). Overall, the epidemiology data of CDI in Europe are more variable due to different reporting systems within the European Union. However, by extrapolation of the data from the United Kingdom to Europe, they result in a total number of 172,000 CDI cases annually within the European Union (Barbut et al., 2013). The epidemic spread of hypervirulent $C$. difficile strains, e.g., PCR ribotype 027 leads to larger nosocomial outbreaks, which are associated with increased morbidity and mortality (Reichardt et al., 2007; Bacci et al., 2011). The economic impact of CDI is enormous, leading to additional medical costs of over one billion dollar per year in the United States and three billion euro per year within the European Union (Kuijper et al., 2006; Dubberke and Olsen, 2012). Especially hospitalized patients and adults in long-term care facilities are at a higher risk of developing CDI (Simor et al., 2002; Bauer et al., 2011; Kim et al., 2011). Additionally, in infants an increase of CDI was observed in the last decade (Zilberberg et al., 2008; Nylund et al., 2011; Khanna et al., 2013; McFarland et al., 2016). This is especially interesting since - as mentioned above - C. difficile is highly prevalent in infants, however, they usually do not show clinical signs of CDI. Nevertheless, the data regarding CDI in pediatric patients are limited.

\section{ASYMPTOMATIC COLONIZATION}

While many studies have focused on the pathogenesis and the development of CDI, the role of asymptomatic C. difficile colonization and its progression to $\mathrm{CDI}$ is still not completely understood. While in the past literature the definition of asymptomatic $C$. difficile colonization is not uniform, FuruyaKanamori et al. (2015) were proposing one as followed: either detectable concentrations of $C$. difficile or its toxin and the absence of diarrhea without colonoscopic or histopathologic findings consistent with pseudomembranous colitis.

The prevalence of asymptomatic $C$. difficile colonization in adults varies in different population groups. In healthy 
adults, several studies have shown that $0-17.5 \%$ were colonized by $C$. difficile strains without clinical signs of CDI (Nakamura et al., 1981; Viscidi et al., 1981; Kobayashi, 1983; Aronsson et al., 1985; Fekety and Shah, 1993; Ozaki et al., 2004; Terveer et al., 2017). The colonization rate of toxigenic strains ranges from 1 to $5 \%$ in the surveyed group. While the prevalence of asymptomatic $C$. difficile colonization is relatively low in healthy adults, it can rise dramatically in individuals having contact with the health system. Elderly in long-term care facilities or nursing homes have an increased rate of colonization range from 0 to 51\% (Campbell et al., 1988; Riggs et al., 2007; Arvand et al., 2012). A high prevalence of asymptomatic C. difficile can also be found in patients or health-care workers (McFarland et al., 1989; Samore et al., 1994; Kato et al., 2001; Hell et al., 2012; Guerrero et al., 2013; Leekha et al., 2013). Additionally, patients in rehabilitation centers have an increased rate of asymptomatic $C$. difficile colonization (Marciniak et al., 2006; Stevens et al., 2011). Furthermore, a high percentage of asymptomatic $C$. difficile colonization can be found in adult patients with underlying diseases, e.g., cystic fibrosis (Welkon et al., 1985; Peach et al., 1986; Bauer et al., 2014).

Risk factors for the development of the last asymptomatic C. difficile colonization are hospitalization within 12 months, use of corticosteroids, a previous history of CDI and antibodies against toxin B (Kong et al., 2015).

In contrast to adults, a high prevalence of $C$. difficile colonization without clinical signs of CDI can be observed in infants and neonates (Thompson et al., 1983; Rousseau et al., 2012). Especially in the first 4 weeks of life, C. difficile colonization increases from $0 \%$ to an average of $37 \%$, followed by a recovery, dropping to an average of $10 \%$ during the first year of life (Bolton et al., 1984; Jangi and Lamont, 2010). Colonization rates comparable to the rates in healthy adults were observed in infants by the age of 2 (Hafiz and Oakley, 1976). Analysis of ribotypes revealed that pediatric patients harbor several toxigenic strains that circulate in adult patients (Schwartz et al., 2014; van Dorp et al., 2017).

Although - according to the definition - asymptomatic colonized individuals show no clinical signs of CDI, they can act as a reservoir of $C$. difficile and also may serve as potential disease carriers and might therefore transmit $C$. difficile to others (McFarland et al., 1989; Riggs et al., 2007; Curry et al., 2013; Eyre et al., 2013). Furthermore, asymptomatic colonization with C. difficile is a crucial factor in the progression to CDI, as carriers of toxigenic strains are at a higher risk for the development of an infection compared to non-colonized patients (Zacharioudakis et al., 2015).

In contrast to this, asymptomatic colonization could also induce the production of antibodies, which in turn protect their host against CDI with a humoral immune response (Shim et al., 1998; Kyne et al., 2000, 2001). It was also proposed that asymptomatic $C$. difficile colonization might lead to the integration of $C$. difficile into the indigenous intestinal microbiota, serving as a protective factor for the development of CDI (Vincent et al., 2016). This theory could also be proven in hamsters, where colonization with a non-toxigenic $C$. difficile strain before the application of a toxigenic $C$. difficile strain was able to prevent the development of CDI (Sambol et al., 2002; Merrigan et al., 2003, 2009). However, further prospective studies to better understand the mechanisms how individuals develop asymptomatic $C$. difficile colonization and if this may act as risk or protective factor in the progression for an infection are needed.

\section{FROM COLONIZATION TO INFECTION}

A schematic overview which factors lead to the development of CDI is given in Figure 1.

\section{Host Factors}

\section{The Indigenous Microbiota}

The intestinal microbiota is a complex ecosystem consisting of over a thousand bacterial species reaching its highest concentration in the colon (Ley et al., 2006; Sekirov et al., 2010; Blaser, 2014). In adults, a healthy intestinal microbiota is dominated by the phyla Bacteroidetes and Firmicutes and shows a high diversity and richness (Rajilić-Stojanović et al., 2009). These commensal bacteria are essential for the host metabolism, nutrition function, maturation of the immune system and protection against pathogens. During human lifetime, different factors, such as the mode of delivery, diet, geography, antibiotic use and the development of gastrointestinal diseases can influence the composition of the intestinal microbiota (Schultsz et al., 1999; Huurre et al., 2008; De Filippo et al., 2010; Dominguez-Bello et al., 2010; Jakobsson et al., 2010; Manges et al., 2010; Dethlefsen and Relman, 2011; Muegge et al., 2011; Wu et al., 2011; Yatsunenko et al., 2012; Zupancic et al., 2012; Matamoros et al., 2013; Ringel and Maharshak, 2013). A disruption of this ecosystem, a so-called intestinal dysbiosis can have a significant influence on the structure and the function of the resident microbiota. Changes of the indigenous intestinal microbial composition result in a breakdown of the colonization resistance, which favors $C$. difficile germination, growth and spreading within the intestine (Antonopoulos et al., 2009; Robinson and Young, 2010).

It is well known that the susceptibility of CDI is strongly associated with a previous exposure to antibiotics. The application of antibiotics, especially broad-spectrum antibiotics, can have profound and long-lasting consequences on the host by altering the intestinal bacterial composition and the metabolome (Dethlefsen et al., 2008; Antonopoulos et al., 2009; Peterfreund et al., 2012; Theriot et al., 2014). The first description of CDI in the setting of antibiotic therapy was in 1974 in a patient after the application of clindamycin (Tedesco et al., 1974). Other antibiotics, especially cephalosporins, penicillin and fluoroquinolones have also been reported to be associated with the development of CDI (Bartlett, 2010; Manges et al., 2010). Moreover, it has been demonstrated that cumulative exposure to any kind of antibiotics increases the risk of developing CDI (Stevens et al., 2011). The impact of antibiotic administration on the microbial composition in healthy adults has been studied extensively. Sullivan et al. (2001) summarized the effects of different antimicrobial agents on the bacterial diversity and single bacterial phylae, families and 


\section{Asymptomatic colonization}

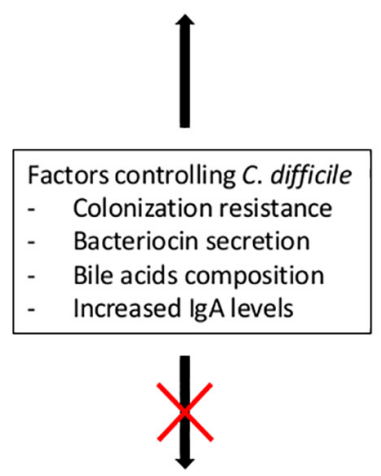

\section{C. difficile infection (CDI)}

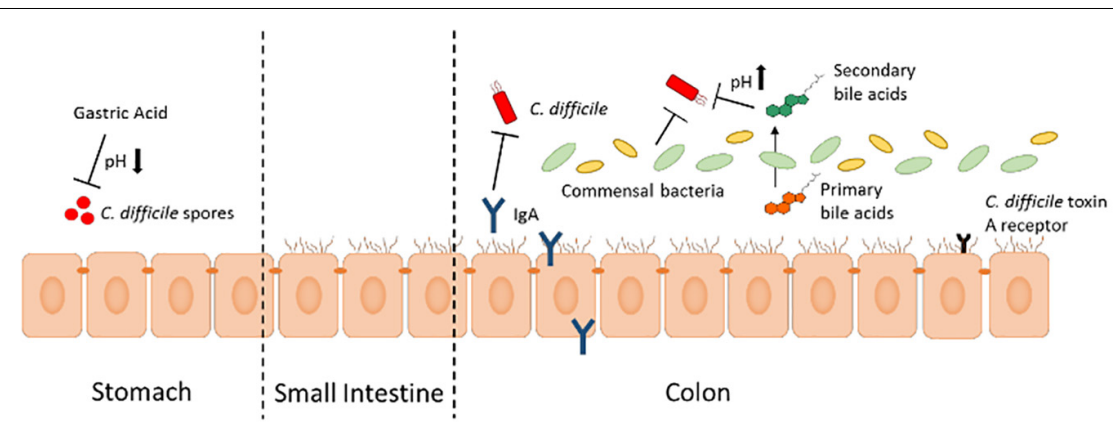

Risk Factors

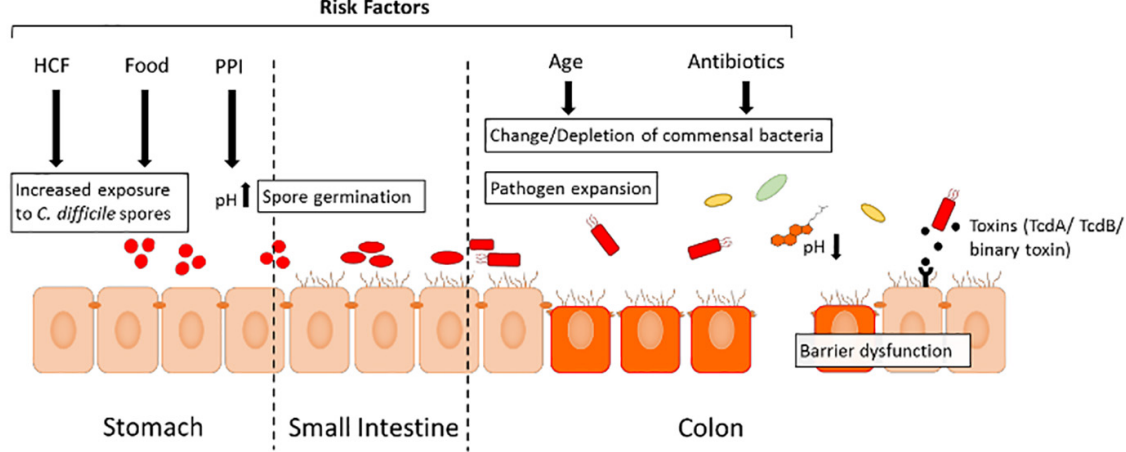

FIGURE 1 | Processes leading from asymptomatic $C$. difficile colonization to CDI. Different factors can prevent an asymptomatic individual from the development of CDI. Gastric acid production within the stomach prevents further spreading of the spores. A healthy indigenous intestinal microbial composition serves as a colonization resistance, can produce bacteriocins limiting $C$. difficile expansion and compete with nutritional contents. Additionally, a change in the bile acid composition can also have effects on the expansion of $C$. difficile. Increased exposure to $C$. difficile, e.g., contact with HCF or via oral ingestion with food, predisposes an individual at risk for asymptomatic colonization. In case of underlying risk factors, an asymptomatic colonization can progress to CDI. After application of antibiotics, a depletion of the commensal bacterial composition can occur leading to a reduced colonization resistance favoring the development of $\mathrm{CDI}$. Other risk factors are increased age, comorbidities and the application of drugs which reduce the gastric acid, e.g., proton pump inhibitors (PPIs). Abbreviations: CDI, C. difficile infection; HCF, health care facilities; IgA, Immunoglobulin A; PPI, proton pump inhibitor; TcdA, C. difficile toxin A; TcdB, C. difficile toxin B.

classes. The effects of antibiotics on the intestinal microbial composition can also be investigated in murine models, allowing the examination of factors which lead to the resistance of C. difficile colonization and subsequent development of CDI (Chen et al., 2008; Reeves et al., 2011, 2012; Buffie et al., 2012; Lawley et al., 2012; Winston et al., 2016). Different studies described the intestinal microbial composition in patients with CDI and observed similar results regarding a reduced diversity and also reduced species richness. In contrast to healthy controls, patients with CDI showed an increase in Firmicutes and Proteobacteria phyla and a decrease in Bacteroidetes phylum. Furthermore, Ruminococcacea, Lachnospiraceae, Bacteriodaceae, Clostrida cluster IV and XIVa are decreased while an increased abundance of Enterococacea could be observed (Chang et al., 2008; Antharam et al., 2013; Hamilton et al., 2013). Additionally, in a study by Vincent et al. (2013, 2016), co-colonization with potentially protective bacterial taxa, e.g., Clostridiales Family XI Incertae Sedis, Clostridium or Eubacterium may protect the development of CDI from asymptomatic $C$. difficile colonization. In a recent study by Pakpour et al. (2017), Veillonella dispar was found as a candidate organism which might be protective for the recurrence of C. difficile.

\section{Bile Acids}

Germination of $C$. difficile spores is supported by changes in the composition of bile acids (Jump et al., 2007; Howerton et al., 2011). A reduced number of bacteria, producing hydrolase enzymes, results in a reduction of secondary bile acids, which normally inhibit vegetative cell growth and a simultaneous increase of primary bile acids like cholate or taurocholic acid stimulates spore germination (Sorg and Sonenshein, 2008). While cholate and glycine can promote $C$. difficile spore formation, chenodeoxycholate was found to act as an inhibitor of spore formation (Wilson, 1983; Sorg and Sonenshein, 2008). A depletion of commensals can also result in an oversupply of available nutrients, e.g., monosaccharides, which can further be utilized by C. difficile (Wilson and Perini, 1988; Begley et al., 2006). In a murine model, administration of antibiotics led to a shift of the bile acid pool and therefore increased $C$. difficile spore germination (Giel et al., 2010; Antunes and Finlay, 2011).

\section{Bacteriocins}

Bacteriocins are ribosomally synthesized antimicrobial peptides with narrow or broad spectrum activity against other bacterial species (Bacon et al., 1988; Cotter et al., 2005). The secretion of bacteriocins from Bacillus, Lactococcus, and Enterococcus strains, 
whose antimicrobial function against $C$. difficile has been proven in vitro, is decreased in CDI (Bartoloni et al., 2004; Rea et al., 2007; Trzasko et al., 2012).

\section{Difficile Toxin A Receptor}

The susceptibility of the host to CDI is also associated with the presence or absence of $C$. difficile toxin A receptor on the surface of intestinal epithelial cells. This fact was reinforced by the study of Eglow et al. (1992) which compared the effect of toxin $\mathrm{A}$ in newborn compared to adult rabbit ileum. The absence of pathological effects in the newborn ileum may be due to a complete lack or only a low expression of $C$. difficile toxin A receptor and therefore might prevent neonates from the development a CDI.

\section{Immunological Factors}

It is well known that the host recognition of $C$. difficile and the subsequent innate and adaptive immune responses have a protective effect against the development of CDI (Cowardin and Petri, 2014; Buonomo and Petri, 2016). Kyne et al. (2000) tested prospectively the immune response of the host via measuring IgG antibodies of TcdA and found that an acquired antibody response to $C$. difficile protected against CDI. However, the antibody response to $C$. difficile did not affect asymptomatic $C$. difficile colonization.

The protective effect of high IgA concentrations, which is a potent toxin A neutralizer has also been shown in breastfeed infants (Rolfe and Song, 1995). The presence of maternal secretory IgA may prevent them from colonization, as this cohort was found to have lower recovery rates compared to formulafed infants (Viscidi et al., 1981; Larson et al., 1982; Stark and Lee, 1982; Richardson et al., 1983; Wongwanich et al., 2001). However, beneath IgA also other components of breast milk have the potential to bind C. difficile toxin A (Rolfe and Song, 1995; Naaber et al., 1996).

\section{Bacterial Factors}

The development of CDI is closely linked to the bacterial virulence factors $\mathrm{Tcd} A$ and $\mathrm{TcdB}$ and the binary toxin, as nontoxigenic $C$. difficile strains are not known to cause CDI (Geric et al., 2006). Colonization with hypervirulent ribotype NAP1 occurred more likely in CDI than in asymptomatic colonized individuals, due to an increased TcdA and TcdB production compared to other toxigenic ribotypes (Warny et al., 2005; Loo et al., 2011; Alasmari et al., 2014).

\section{Extrinsic Risk Factors}

Different studies indicate that - beneath host-mediated and pathogen-related factors - multiple extrinsic risk factors increase the development and also severity of CDI.

\section{Antibiotics}

As described above, the use of antibiotics is the most-common risk factor in the development of CDI. Antibiotics have dramatic effects on the bacterial ecosystem of the gut, which can last for a long period of time (Dethlefsen et al., 2008; Antonopoulos et al., 2009). Especially fluoroquinolones and particularly cephalosporins and clindamycin are associated with an increased frequency of CDI (Nelson et al., 1994; McCusker et al., 2003; Muto et al., 2005; McFarland et al., 2007b; Kallen et al., 2009).

\section{Proton Pump Inhibitors}

Another important risk factor for the development of CDI is the use of proton pump inhibitors (PPIs) (Dial et al., 2004; Akhtar and Shaheen, 2007; Deshpande et al., 2012). While the normal gastric acidity provides a protective host defense, an increase of the gastric $\mathrm{pH}$ may prevent the gastric content from an elimination of the ingested C. difficile spores (Bavishi and Dupont, 2011). However, the role of PPIs in the development of CDI is still controversial, since other studies could not prove an association between the gastric acid suppression and an increased risk for the development of CDI (Novack et al., 2014; Khanafer et al., 2017). Since the use of PPIs is increasing globally, further prospective studies are needed in order to address the possible association with these drugs and the development of asymptomatic $C$. difficile colonization or CDI.

\section{Health Care Facilities}

In hospitals or long-term care facilities, an increased exposure to C. difficile can be found due to high $C$. difficile contamination on surfaces, medical devices and health care personal or infected roommates (McFarland et al., 1989; Chang and Nelson, 2000). Furthermore, a high rate of polypharmacy like antibiotics and underlying co-morbidities such as malignancy or inflammatory bowel disease are closely associated with patients in health care facilities (Morris et al., 1984; Rea et al., 2007). To decrease the C. difficile transmission and infection rate in hospitals and longterm care facilities, a screening of new patients could be an option to identify toxigenic strain carriers and isolate them from other patients. These approach was able to significantly decrease the incidence of hospital acquired CDI in a prospective Canadian study cohort (Longtin et al., 2016).

\section{Age}

Clostridium difficile is more common in advanced age, also showing a more severe outcome in this population (Loo et al., 2005; Pépin et al., 2005; Henrich et al., 2009; Miller et al., 2010). There are several possible mechanisms for this phenomenon. First, an inadequate innate or humoral immune response might lead to a higher incidence and also severity of CDI (Kelly, 1996; Mariat et al., 2009; Ogra, 2010). Secondarily, the higher prevalence of CDI in the elderly could also be associated with the change of the intestinal microbial composition, e.g., loss of bacterial diversity during aging, which might promote C. difficile colonization (Hopkins et al., 2001; Woodmansey, 2007). Additionally, the presence of chronic disorders and an increase in the infection rate, requiring polypharmacy, including antibiotics, is generally much higher in this age cohort (Garibaldi and Nurse, 1986; Werner and Kuntsche, 2000; Gao et al., 2018).

\section{C. difficile in Food}

While the transmission of $C$. difficile from humans to humans is well-established, C. difficile as a foodborne disease still remains 
a matter of debate. In different studies, $C$. difficile was found in retail meat (Rodriguez-Palacios et al., 2007, 2009). Additionally, C. difficile was also detected in water, vegetables, pets and also piglets (Borriello et al., 1983; al Saif and Brazier, 1996; Keel et al., 2007; Songer et al., 2007; Yaeger et al., 2007; Clooten et al., 2008; Pirs et al., 2008; Bakri et al., 2009). Regular exposure to C. difficile in the food might lead to asymptomatic C. difficile colonization. However, since community-acquired C. difficile is relatively uncommon, it is not clear if the ingestion of $C$. difficile via the oral route also leads to consecutive CDI. Further studies will be needed in order to address this issue.

\section{TREATMENT OF CDI}

\section{Conventional}

The mainstay in the treatment of $\mathrm{CDI}$ is - beneath the withdrawal of antibiotics fostering CDI - the initiation of an antibiotic therapy, e.g., vancomycin or metronidazole (Debast et al., 2014; Hagel et al., 2015). Recent advances in the therapy of $C$. difficile and the role of antibiotic resistance in CDI are summarized elsewhere (Spigaglia, 2016). However, therapy of recurrent CDI can be challenging with conventional antibiotic therapy (Cohen et al., 2010; Wilcox et al., 2017). Recurrence of CDI is found in $20-30 \%$ of the patients with a high mortality rate in this cohort (Dubberke and Olsen, 2012). Fidaxomicin, approved by the United States Food and Drug Administration for CDI treatment, shows reduced recurrence rates in patients with C. difficile, however, not in the highly virulent strains B1/NAP1/027 (Louie et al., 2011; Cornely et al., 2012). In a recent study, the use of bezlotoxumab, a human monoclonal antibody against $\mathrm{TcdB}$, was associated with a lower rate of $C$. difficile recurrent infection compared to placebo (Wilcox et al., 2017). The addition of an antibody against TcdA (actoxumab) had no effect on the disease recurrence alone or in combination with bezlotoxumab, which is also underscoring the crucial role of toxin B in the pathogenesis of CDI. A matter of debate for this new approach is the potential combination with fecal microbial transplantation (FMT). Further studies will be needed in order to redefine the treatment algorithm of CDI with bezlotoxumab.

\section{Microbiota-Targeted Therapy}

The intestinal microbial communities of patients with CDI differ from patients with asymptomatic $C$. difficile colonization (Rousseau et al., 2012). In different studies, the administration of single strain probiotics showed only limited success in the treatment of CDI (Pochapin, 2000; Wullt et al., 2003). The role of probiotics in the prevention of CDI is still discussed controversial (Shen et al., 2017; Vernaya et al., 2017). In contrast to this, the probiotic treatment with three strains from Lactobacillus parallel to antibiotic application in hospitalized adults showed a significantly decreased CDI rate from 18.0 to 2.3 cases per 10,000 patients-days during the 10-year observation period (Maziade et al., 2015). The most direct and effective way in changing the patient's intestinal bacterial composition is via FMT. FMT is highly effective in the treatment of antibiotic-refractory CDI and recently was also shown to be cost effective (Kassam et al., 2013; van Nood et al., 2013; Arbel et al., 2017). FMT involves installation of stool from a healthy donor into a patient, leading to a shift of the intestinal microbial communities. Despite the high effectiveness of FMT in the treatment of recurrent CDI, the long-term effects of this therapeutic approach are still not known and might lead to an increased risk of other diseases. Furthermore, FMT is still a highly diverse biological product with several challenges in the standardization of protocols (Arbel et al., 2017). Another therapeutic approach is the administration of non-toxigenic C. difficile strains or a mixture of sporeforming commensals. In two phase II clinical trials testing both treatments, a significant decrease of CDI recurrence was observed (Gerding et al., 2015; Khanna et al., 2016). However, in another study it was observed that non-toxigenic strains had the capacity to change their phenotype to toxigenic $C$. difficile strains (Brouwer et al., 2013). Therefore, non-toxigenic strains can also be a predisposition in the development of CDI and have to be used with caution in the setting of $C$. difficile prevention.

\section{CONCLUSION}

The incidence of CDI increased dramatically in the last years. While asymptomatic $C$. difficile colonization is common especially in newborns, the progression from asymptomatic colonization to infection is not completely understood and large, prospective studies are lacking. While many studies in adults and infants showed high C. difficile colonization rates with toxigenic as well as non-toxigenic strains, the detection of $C$. difficile or its toxins in feces of individuals does not immediately implicate an infection with this pathogen and therefore treatment is only indicated when there are clinical signs of CDI. Although persons with asymptomatic $C$. difficile colonization are potential disease carriers and therefore predispose a risk factor for themselves and other people, based on current information an eradication of $C$. difficile is not indicated. CDI is strongly associated with host-mediated factors, including the indigenous microbiota, bacteriocins, toxin A receptor and immunological factors as well as pathogen-related factors, including $\mathrm{Tcd} A, \mathrm{TcdB}$, and binary toxin. However, host-mediated factors are discussed to have a more pronounced role in the development of CDI (McFarland et al., 1991; Cheng et al., 1997). Especially a disruption of the indigenous intestinal microbial composition within the host can promote the development of CDI via germination and proliferation of toxigenic $C$. difficile strains. Furthermore, several external factors like age, polypharmacy or underlying medical conditions increase the risk and severity of CDI. Due to the strong association between CDI and antibiotic exposure, therapeutic approaches that target the modulation of the intestinal bacterial composition like FMT are crucial in this clinical setting. Treatment strategies with non-toxigenic $C$. difficile strains are on their way, however, a change of non-toxigenic to toxigenic C. difficile strains can occur, making this therapeutic approach challenging. 
The role of asymptomatic $C$. difficile colonization in the development of CDI is still a controversial matter of debate. Further studies elucidating the clinical consequences of asymptomatic $C$. difficile colonization are needed to further investigate if the presence of $C$. difficile without any signs of CDI is beneficial or might potentially be harmful. We conclude that mechanisms that enable the progression from asymptomatic $C$. difficile colonization to CDI are closely associated with host-mediated as well as pathogenrelated factors and a combination of both might be of outstanding interest in the pathogenesis and also prevention of CDI.

\section{AUTHOR'S NOTE}

Due to a limitation of words no citation of all primary literature was possible, the authors kindly ask to excuse this circumstance.

\section{REFERENCES}

Akhtar, A. J., and Shaheen, M. (2007). Increasing incidence of Clostridium difficileassociated diarrhea in African-American and Hispanic patients: association with the use of proton pump inhibitor therapy. J. Natl. Med. Assoc. 99, 500-504.

al Saif, N., and Brazier, J. S. (1996). The distribution of Clostridium difficile in the environment of South Wales. J. Med. Microbiol. 45, 133-137. doi: 10.1099/ 00222615-45-2-133

Alasmari, F., Seiler, S. M., Hink, T., Burnham, C.-A. D., and Dubberke, E. R. (2014). Prevalence and risk factors for asymptomatic Clostridium difficile carriage. Clin. Infect. Dis. 59, 216-222. doi: 10.1093/cid/ciu258

Ananthakrishnan, A. N. (2011). Clostridium difficile infection: epidemiology, risk factors and management. Nat. Rev. Gastroenterol. Hepatol. 8, 17-26. doi: 10.1038/nrgastro.2010.190

Antharam, V. C., Li, E. C., Ishmael, A., Sharma, A., Mai, V., Rand, K. H., et al. (2013). Intestinal dysbiosis and depletion of butyrogenic bacteria in Clostridium difficile infection and nosocomial diarrhea. J. Clin. Microbiol. 51, 2884-2892. doi: 10.1128/JCM.00845-13

Antonopoulos, D. A., Huse, S. M., Morrison, H. G., Schmidt, T. M., Sogin, M. L., and Young, V. B. (2009). Reproducible community dynamics of the gastrointestinal microbiota following antibiotic perturbation. Infect. Immun. 77, 2367-2375. doi: 10.1128/IAI.01520-08

Antunes, L. C. M., and Finlay, B. B. (2011). A comparative analysis of the effect of antibiotic treatment and enteric infection on intestinal homeostasis. Gut Microbes 2, 105-108. doi: 10.4161/gmic.2.2.15610

Arbel, L. T., Hsu, E., and McNally, K. (2017). Cost-effectiveness of fecal microbiota transplantation in the treatment of recurrent Clostridium difficile infection: a literature review. Cureus 9:e1599. doi: 10.7759/cureus.1599

Aronsson, B., Möllby, R., and Nord, C. E. (1985). Antimicrobial agents and Clostridium difficile in acute enteric disease: epidemiological data from Sweden, 1980-1982. J. Infect. Dis. 151, 476-481. doi: 10.1093/infdis/151. 3.476

Arvand, M., Moser, V., Schwehn, C., Bettge-Weller, G., Hensgens, M. P., and Kuijper, E. J. (2012). High prevalence of Clostridium difficile colonization among nursing home residents in Hesse, Germany. PLoS One 7:e30183. doi: 10.1371/journal.pone.0030183

Bacci, S., Mølbak, K., Kjeldsen, M. K., and Olsen, K. E. P. (2011). Binary toxin and death after Clostridium difficile infection. Emerg. Infect. Dis. 17, 976-982. doi: 10.3201/eid/1706.101483

Bacon, A. E., Fekety, R., Schaberg, D. R., and Faix, R. G. (1988). Epidemiology of Clostridium difficile colonization in newborns: results using a bacteriophage and bacteriocin typing system. J. Infect. Dis. 158, 349-354. doi: 10.1093/infdis/158. 2.349

\section{AUTHOR CONTRIBUTIONS}

All authors listed have made a substantial, direct and intellectual contribution to the work, and approved it for publication.

\section{FUNDING}

HS received a research grant from the Damp Foundation (2016-04).

\section{ACKNOWLEDGMENTS}

$\mathrm{AB}$ thanks the Federal State Government of MecklenburgVorpommern, Ministry of Education, Science and Culture, Grant No. AU 15002.

Bagdasarian, N., Rao, K., and Malani, P. N. (2015). Diagnosis and treatment of Clostridium difficile in adults: a systematic review. JAMA 313, 398-408. doi: 10.1001/jama.2014.17103

Bakri, M. M., Brown, D. J., Butcher, J. P., and Sutherland, A. D. (2009). Clostridium difficile in ready-to-eat salads, Scotland. Emerg. Infect. Dis. 15, 817-818. doi: 10.3201/eid1505.081186

Barbut, F., Cornely, O. A., Fitzpatrick, F., Kuijper, E. J., Nagy, E., Rupnik, M., et al. (2013). Clostridium difficile Infection in Europe: A CDI Europe Report. Available at: http://www.multivu.com/assets/60637/documents/60637CDI-HCP-Report-original.pdf [accessed March 05, 2018].

Bartlett, J. G. (2006). Narrative review: the new epidemic of Clostridium difficileassociated enteric disease. Ann. Intern. Med. 145, 758-764. doi: 10.7326/00034819-145-10-200611210-00008

Bartlett, J. G. (2010). Clostridium difficile: progress and challenges. Ann. N. Y. Acad. Sci. 1213, 62-69. doi: 10.1111/j.1749-6632.2010.05863.x

Bartlett, J. G., Chang, T. W., and Onderdonk, A. B. (1978). Comparison of five regimens for treatment of experimental clindamycin-associated colitis. J. Infect. Dis. 138, 81-86. doi: 10.1093/infdis/138.1.81

Bartlett, J. G., Onderdonk, A. B., Cisneros, R. L., and Kasper, D. L. (1977). Clindamycin-associated colitis due to a toxin-producing species of Clostridium in hamsters. J. Infect. Dis. 136, 701-705. doi: 10.1093/infdis/136. 5.701

Bartoloni, A., Mantella, A., Goldstein, B. P., Dei, R., Benedetti, M., Sbaragli, S., et al. (2004). In-vitro activity of nisin against clinical isolates of Clostridium difficile. J. Chemother. 16, 119-121. doi: 10.1179/joc.2004.16.2.119

Bauer, M. P., Farid, A., Bakker, M., Hoek, R. A. S., Kuijper, E. J., and van Dissel, J. T. (2014). Patients with cystic fibrosis have a high carriage rate of non-toxigenic Clostridium difficile. Clin. Microbiol. Infect. 20, O446-O449. doi: 10.1111/14690691.12439

Bauer, M. P., Notermans, D. W., van Benthem, B. H. B., Brazier, J. S., Wilcox, M. H., Rupnik, M., et al. (2011). Clostridium difficile infection in Europe: a hospital-based survey. Lancet 377, 63-73. doi: 10.1016/S0140-6736(10)61 266-4

Bavishi, C., and Dupont, H. L. (2011). Systematic review: the use of proton pump inhibitors and increased susceptibility to enteric infection. Aliment. Pharmacol. Ther. 34, 1269-1281. doi: 10.1111/j.1365-2036.2011.04874.x

Begley, M., Hill, C., and Gahan, C. G. M. (2006). Bile salt hydrolase activity in probiotics. Appl. Environ. Microbiol. 72, 1729-1738. doi: 10.1128/AEM.72.3. 1729-1738.2006

Blaser, M. J. (2014). The microbiome revolution. J. Clin. Invest. 124, 4162-4165. doi: 10.1172/JCI78366

Bolton, R. P., Tait, S. K., Dear, P. R., and Losowsky, M. S. (1984). Asymptomatic neonatal colonisation by Clostridium difficile. Arch. Dis. Child. 59, 466-472. doi: 10.1136/adc.59.5.466 
Borriello, S. P., Honour, P., Turner, T., and Barclay, F. (1983). Household pets as a potential reservoir for Clostridium difficile infection. J. Clin. Pathol. 36, 84-87. doi: $10.1136 /$ jcp.36.1.84

Brouwer, M. S. M., Roberts, A. P., Hussain, H., Williams, R. J., Allan, E., and Mullany, P. (2013). Horizontal gene transfer converts non-toxigenic Clostridium difficile strains into toxin producers. Nat. Commun. 4:2601. doi: $10.1038 /$ ncomms3601

Buffie, C. G., Bucci, V., Stein, R. R., McKenney, P. T., Ling, L., Gobourne, A., et al. (2015). Precision microbiome reconstitution restores bile acid mediated resistance to Clostridium difficile. Nature 517, 205-208. doi: 10.1038/ nature 13828

Buffie, C. G., Jarchum, I., Equinda, M., Lipuma, L., Gobourne, A., Viale, A., et al. (2012). Profound alterations of intestinal microbiota following a single dose of clindamycin results in sustained susceptibility to Clostridium difficile-induced colitis. Infect. Immun. 80, 62-73. doi: 10.1128/IAI.05496-11

Buonomo, E. L., and Petri, W. A. (2016). The microbiota and immune response during Clostridium difficile infection. Anaerobe 41, 79-84. doi: 10.1016/j. anaerobe.2016.05.009

Campbell, R. R., Beere, D., Wilcock, G. K., and Brown, E. M. (1988). Clostridium difficile in acute and long-stay elderly patients. Age Ageing 17, 333-336. doi: 10.1093/ageing/17.5.333

Carroll, K. C., and Bartlett, J. G. (2011). Biology of Clostridium difficile: implications for epidemiology and diagnosis. Annu. Rev. Microbiol. 65, 501521. doi: 10.1146/annurev-micro-090110-102824

Chang, J. Y., Antonopoulos, D. A., Kalra, A., Tonelli, A., Khalife, W. T., Schmidt, T. M., et al. (2008). Decreased diversity of the fecal Microbiome in recurrent Clostridium difficile-associated diarrhea. J. Infect. Dis. 197, 435-438. doi: $10.1086 / 525047$

Chang, V. T., and Nelson, K. (2000). The role of physical proximity in nosocomial diarrhea. Clin. Infect. Dis. 31, 717-722. doi: 10.1086/314030

Chen, X., Katchar, K., Goldsmith, J. D., Nanthakumar, N., Cheknis, A., Gerding, D. N., et al. (2008). A mouse model of Clostridium difficile-associated disease. Gastroenterology 135, 1984-1992. doi: 10.1053/j.gastro.2008.09.002

Cheng, S. H., Lu, J. J., Young, T. G., Perng, C. L., and Chi, W. M. (1997). Clostridium difficile-associated diseases: comparison of symptomatic infection versus carriage on the basis of risk factors, toxin production, and genotyping results. Clin. Infect. Dis. 25, 157-158. doi: 10.1086/516891

Clooten, J., Kruth, S., Arroyo, L., and Weese, J. S. (2008). Prevalence and risk factors for Clostridium difficile colonization in dogs and cats hospitalized in an intensive care unit. Vet. Microbiol. 129, 209-214. doi: 10.1016/j.vetmic.2007. 11.013

Cohen, S. H., Gerding, D. N., Johnson, S., Kelly, C. P., Loo, V. G., McDonald, L. C., et al. (2010). Clinical practice guidelines for Clostridium difficile infection in adults: 2010 update by the society for healthcare epidemiology of America (SHEA) and the infectious diseases society of America (IDSA). Infect. Control Hosp. Epidemiol. 31, 431-455. doi: 10.1086/651706

Cornely, O. A., Crook, D. W., Esposito, R., Poirier, A., Somero, M. S., Weiss, K., et al. (2012). Fidaxomicin versus vancomycin for infection with Clostridium difficile in Europe, Canada, and the USA: a double-blind, non-inferiority, randomised controlled trial. Lancet Infect. Dis. 12, 281-289. doi: 10.1016/ S1473-3099(11)70374-7

Cotter, P. D., Hill, C., and Ross, R. P. (2005). Bacteriocins: developing innate immunity for food. Nat. Rev. Microbiol. 3, 777-788. doi: 10.1038/nrmicro1273

Cowardin, C. A., and Petri, W. A. (2014). Host recognition of Clostridium difficile and the innate immune response. Anaerobe 30, 205-209. doi: 10.1016/j. anaerobe.2014.08.014

Curry, S. R., Marsh, J. W., Muto, C. A., O’Leary, M. M., Pasculle, A. W., and Harrison, L. H. (2007). tcdC genotypes associated with severe TcdC truncation in an epidemic clone and other strains of Clostridium difficile. J. Clin. Microbiol. 45, 215-221. doi: 10.1128/JCM.01599-06

Curry, S. R., Muto, C. A., Schlackman, J. L., Pasculle, A. W., Shutt, K. A., Marsh, J. W., et al. (2013). Use of multilocus variable number of tandem repeats analysis genotyping to determine the role of asymptomatic carriers in Clostridium difficile transmission. Clin. Infect. Dis. 57, 1094-1102. doi: 10.1093/cid/cit475

De Filippo, C., Cavalieri, D., Di Paola, M., Ramazzotti, M., Poullet, J. B., Massart, S., et al. (2010). Impact of diet in shaping gut microbiota revealed by a comparative study in children from Europe and rural Africa. Proc. Natl. Acad. Sci. U.S.A. 107, 14691-14696. doi: 10.1073/pnas.1005963107
Debast, S. B., Bauer, M. P., and Kuijper, E. J. (2014). European Society of Clinical Microbiology and Infectious Diseases: update of the treatment guidance document for Clostridium difficile infection. Clin. Microbiol. Infect. 20(Suppl. 2), 1-26. doi: 10.1111/1469-0691.12418

Deshpande, A., Pant, C., Pasupuleti, V., Rolston, D. D. K., Jain, A., Deshpande, N., et al. (2012). Association between proton pump inhibitor therapy and Clostridium difficile infection in a meta-analysis. Clin. Gastroenterol. Hepatol. 10, 225-233. doi: 10.1016/j.cgh.2011.09.030

Dethlefsen, L., Huse, S., Sogin, M. L., and Relman, D. A. (2008). The pervasive effects of an antibiotic on the human gut microbiota, as revealed by deep $16 \mathrm{~S}$ rRNA sequencing. PLoS Biol. 6:e280. doi: 10.1371/journal.pbio.0060280

Dethlefsen, L., and Relman, D. A. (2011). Incomplete recovery and individualized responses of the human distal gut microbiota to repeated antibiotic perturbation. Proc. Natl. Acad. Sci. U.S.A. 108(Suppl. 1), 4554-4561. doi: $10.1073 /$ pnas. 1000087107

Dial, S., Alrasadi, K., Manoukian, C., Huang, A., and Menzies, D. (2004). Risk of Clostridium difficile diarrhea among hospital inpatients prescribed proton pump inhibitors: cohort and case-control studies. CMAJ 171, 33-38. doi: 10. 1503/cmaj.1040876

Dominguez-Bello, M. G., Costello, E. K., Contreras, M., Magris, M., Hidalgo, G., Fierer, N., et al. (2010). Delivery mode shapes the acquisition and structure of the initial microbiota across multiple body habitats in newborns. Proc. Natl. Acad. Sci. U.S.A. 107, 11971-11975. doi: 10.1073/pnas.1002 601107

Drudy, D., Fanning, S., and Kyne, L. (2007). Toxin A-negative, toxin B-positive Clostridium difficile. Int. J. Infect. Dis. 11, 5-10. doi: 10.1016/j.ijid.2006.04.003

Dubberke, E. R., and Olsen, M. A. (2012). Burden of Clostridium difficile on the healthcare system. Clin. Infect. Dis. 55(Suppl. 2), S88-S92. doi: 10.1093/cid/ cis335

Dupuy, B., Govind, R., Antunes, A., and Matamouros, S. (2008). Clostridium difficile toxin synthesis is negatively regulated by TcdC. J. Med. Microbiol. 57, 685-689. doi: 10.1099/jmm.0.47775-0

Eglow, R., Pothoulakis, C., Itzkowitz, S., Israel, E. J., O’Keane, C. J., Gong, D., et al. (1992). Diminished Clostridium difficile toxin A sensitivity in newborn rabbit ileum is associated with decreased toxin A receptor. J. Clin. Invest. 90, 822-829. doi: $10.1172 /$ JCI115957

Eyre, D. W., Griffiths, D., Vaughan, A., Golubchik, T., Acharya, M., O’Connor, L., et al. (2013). Asymptomatic Clostridium difficile colonisation and onward transmission. PLoS One 8:e78445. doi: 10.1371/journal.pone.0078445

Fekety, R., and Shah, A. B. (1993). Diagnosis and treatment of Clostridium difficile colitis. JAMA 269, 71-75. doi: 10.1001/jama.1993.03500010081036

Furuya-Kanamori, L., Marquess, J., Yakob, L., Riley, T. V., Paterson, D. L., Foster, N. F., et al. (2015). Asymptomatic Clostridium difficile colonization: epidemiology and clinical implications. BMC Infect. Dis. 15:516. doi: 10.1186/ s12879-015-1258-4

Gao, L., Maidment, I., Matthews, F. E., Robinson, L., and Brayne, C. (2018). Medication usage change in older people $(65+)$ in England over 20 years: findings from CFAS I and CFAS II. Age Ageing 47, 220-225. doi: 10.1093/ageing/ afx158

Garibaldi, R. A., and Nurse, B. A. (1986). Infections in the elderly. Am. J. Med. 81, 53-58. doi: 10.1016/0002-9343(86)90514-0

Gerding, D. N., Johnson, S., Peterson, L. R., Mulligan, M. E., and Silva, J. (1995). Clostridium difficile-associated diarrhea and colitis. Infect. Control Hosp. Epidemiol. 16, 459-477. doi: 10.2307/30141083

Gerding, D. N., Johnson, S., Rupnik, M., and Aktories, K. (2014). Clostridium difficile binary toxin CDT: mechanism, epidemiology, and potential clinical importance. Gut Microbes 5, 15-27. doi: 10.4161/gmic.26854

Gerding, D. N., Meyer, T., Lee, C., Cohen, S. H., Murthy, U. K., Poirier, A., et al. (2015). Administration of spores of nontoxigenic Clostridium difficile strain M3 for prevention of recurrent $C$. difficile infection: a randomized clinical trial. JAMA 313, 1719-1727. doi: 10.1001/jama.2015.3725

Gerding, D. N., Muto, C. A., and Owens, R. C. (2008). Measures to control and prevent Clostridium difficile infection. Clin. Infect. Dis. 46(Suppl. 1), S43-S49. doi: $10.1086 / 521861$

Geric, B., Carman, R. J., Rupnik, M., Genheimer, C. W., Sambol, S. P., Lyerly, D. M., et al. (2006). Binary toxin-producing, large clostridial toxin-negative Clostridium difficile strains are enterotoxic but do not cause disease in hamsters. J. Infect. Dis. 193, 1143-1150. doi: 10.1086/501368 
Giel, J. L., Sorg, J. A., Sonenshein, A. L., and Zhu, J. (2010). Metabolism of bile salts in mice influences spore germination in Clostridium difficile. PLoS One 5:e8740. doi: 10.1371 /journal.pone. 0008740

Gil, F., Lagos-Moraga, S., Calderón-Romero, P., Pizarro-Guajardo, M., and Paredes-Sabja, D. (2017). Updates on Clostridium difficile spore biology. Anaerobe 45, 3-9. doi: 10.1016/j.anaerobe.2017.02.018

Guerrero, D. M., Becker, J. C., Eckstein, E. C., Kundrapu, S., Deshpande, A., Sethi, A. K., et al. (2013). Asymptomatic carriage of toxigenic Clostridium difficile by hospitalized patients. J. Hosp. Infect. 85, 155-158. doi: 10.1016/j.jhin.2013.07. 002

Hafiz, S., and Oakley, C. L. (1976). Clostridium difficile: isolation and characteristics. J. Med. Microbiol. 9, 129-136. doi: 10.1099/00222615-92-129

Hagel, S., Epple, H.-J., Feurle, G. E., Kern, W. V., Lynen Jansen, P., Malfertheiner, P., et al. (2015). S2k-Leitlinie Gastrointestinale Infektionen und Morbus Whipple. Z. Gastroenterol. 53, 418-459. doi: 10.1055/s-0034-139 9337

Hall, I. C., and O'Toole E. (1935). Intestinal flora in new-born infants: with a description of a new pathogenic anaerobe, Bacillus difficilis. Am. J. Dis. Child. 2, 390-402. doi: 10.1001/archpedi.1935.01970020105010

Hamilton, M. J., Weingarden, A. R., Unno, T., Khoruts, A., and Sadowsky, M. J. (2013). High-throughput DNA sequence analysis reveals stable engraftment of gut microbiota following transplantation of previously frozen fecal bacteria. Gut Microbes 4, 125-135. doi: 10.4161/gmic.23571

Hell, M., Sickau, K., Chmelizek, G., Kern, J. M., Maass, M., Huhulescu, S., et al. (2012). Absence of Clostridium difficile in asymptomatic hospital staff. Am. J. Infect. Control 40, 1023-1024. doi: 10.1016/j.ajic.2012.01.018

Henrich, T. J., Krakower, D., Bitton, A., and Yokoe, D. S. (2009). Clinical risk factors for severe Clostridium difficile-associated disease. Emerg. Infect. Dis. 15, 415-422. doi: 10.3201/eid1503.080312

Hopkins, M. J., Sharp, R., and Macfarlane, G. T. (2001). Age and disease related changes in intestinal bacterial populations assessed by cell culture, 16S rRNA abundance, and community cellular fatty acid profiles. Gut 48, 198-205. doi: 10.1136/gut.48.2.198

Howerton, A., Ramirez, N., and Abel-Santos, E. (2011). Mapping interactions between germinants and Clostridium difficile spores. J. Bacteriol. 193, 274-282. doi: 10.1128/JB.00980- 10

Huurre, A., Kalliomäki, M., Rautava, S., Rinne, M., Salminen, S., and Isolauri, E. (2008). Mode of delivery - effects on gut microbiota and humoral immunity. Neonatology 93, 236-240. doi: 10.1159/000111102

Ishida, Y., Maegawa, T., Kondo, T., Kimura, A., Iwakura, Y., Nakamura, S., et al. (2004). Essential involvement of IFN-gamma in Clostridium difficile toxin A-induced enteritis. J. Immunol. 172, 3018-3025. doi: 10.4049/jimmunol.172. 5.3018

Jakobsson, H. E., Jernberg, C., Andersson, A. F., Sjölund-Karlsson, M., Jansson, J. K., and Engstrand, L. (2010). Short-term antibiotic treatment has differing long-term impacts on the human throat and gut microbiome. PLoS One 5:e9836. doi: 10.1371/journal.pone.0009836

Jangi, S., and Lamont, J. T. (2010). Asymptomatic colonization by Clostridium difficile in infants: implications for disease in later life. J. Pediatr. Gastroenterol. Nutr. 51, 2-7. doi: 10.1097/MPG.0b013e3181d29767

Jump, R. L. P., Pultz, M. J., and Donskey, C. J. (2007). Vegetative Clostridium difficile survives in room air on moist surfaces and in gastric contents with reduced acidity: a potential mechanism to explain the association between proton pump inhibitors and C. difficile-associated diarrhea? Antimicrob. Agents Chemother. 51, 2883-2887. doi: 10.1128/AAC.01443-06

Kallen, A. J., Thompson, A., Ristaino, P., Chapman, L., Nicholson, A., Sim, B.-T., et al. (2009). Complete restriction of fluoroquinolone use to control an outbreak of Clostridium difficile infection at a community hospital. Infect. Control Hosp. Epidemiol. 30, 264-272. doi: 10.1086/595694

Kassam, Z., Lee, C. H., Yuan, Y., and Hunt, R. H. (2013). Fecal microbiota transplantation for Clostridium difficile infection: systematic review and metaanalysis. Am. J. Gastroenterol. 108, 500-508. doi: 10.1038/ajg.2013.59

Kato, H., Kita, H., Karasawa, T., Maegawa, T., Koino, Y., Takakuwa, H., et al. (2001). Colonisation and transmission of Clostridium difficile in healthy individuals examined by PCR ribotyping and pulsed-field gel electrophoresis. J. Med. Microbiol. 50, 720-727. doi: 10.1099/0022-1317-50-8-720
Keel, K., Brazier, J. S., Post, K. W., Weese, S., and Songer, J. G. (2007). Prevalence of PCR ribotypes among Clostridium difficile isolates from pigs, calves, and other species. J. Clin. Microbiol. 45, 1963-1964. doi: 10.1128/JCM.002 24-07

Kelly, C. P. (1996). Immune response to Clostridium difficile infection. Eur. J. Gastroenterol. Hepatol. 8, 1048-1053. doi: 10.1097/00042737-199611000-00004

Kelly, C. P., and LaMont, J. T. (1998). Clostridium difficile infection. Annu. Rev. Med. 49, 375-390. doi: 10.1146/annurev.med.49.1.375

Khanafer, N., Vanhems, P., Barbut, F., and Luxemburger, C. (2017). Factors associated with Clostridium difficile infection: a nested case-control study in a three year prospective cohort. Anaerobe 44, 117-123. doi: 10.1016/j.anaerobe. 2017.03.003

Khanna, S., Baddour, L. M., Huskins, W. C., Kammer, P. P., Faubion, W. A., Zinsmeister, A. R., et al. (2013). The epidemiology of Clostridium difficile infection in children: a population-based study. Clin. Infect. Dis. 56, 1401-1406. doi: $10.1093 / \mathrm{cid} / \mathrm{cit} 075$

Khanna, S., Pardi, D. S., Kelly, C. R., Kraft, C. S., Dhere, T., Henn, M. R., et al. (2016). A novel microbiome therapeutic increases gut microbial diversity and prevents recurrent Clostridium difficile infection. J. Infect. Dis. 214, 173-181. doi: 10.1093/infdis/jiv766

Kim, J. H., Toy, D., and Muder, R. R. (2011). Clostridium difficile infection in a long-term care facility: hospital-associated illness compared with longterm care-associated illness. Infect. Control Hosp. Epidemiol. 32, 656-660. doi: $10.1086 / 660767$

Kobayashi, T. (1983). Studies on Clostridium difficile and antimicrobial associated diarrhea or colitis. Jpn. J. Antibiot. 36, 464-476.

Komatsu, M., Kato, H., Aihara, M., Shimakawa, K., Iwasaki, M., Nagasaka, Y., et al. (2003). High frequency of antibiotic-associated diarrhea due to toxin A-negative, toxin B-positive Clostridium difficile in a hospital in Japan and risk factors for infection. Eur. J. Clin. Microbiol. Infect. Dis. 22, 525-529. doi: 10.1007/s10096-003-0992-5

Kong, L. Y., Dendukuri, N., Schiller, I., Bourgault, A.-M., Brassard, P., Poirier, L., et al. (2015). Predictors of asymptomatic Clostridium difficile colonization on hospital admission. Am. J. Infect. Control 43, 248-253. doi: 10.1016/j.ajic.2014. 11.024

Kuijper, E. J., Coignard, B., and Tüll, P. (2006). Emergence of Clostridium difficileassociated disease in North America and Europe. Clin. Microbiol. Infect. 12(Suppl. 6), 2-18. doi: 10.1111/j.1469-0691.2006.01580.x

Kyne, L., Warny, M., Qamar, A., and Kelly, C. P. (2000). Asymptomatic carriage of Clostridium difficile and serum levels of IgG antibody against toxin A. N. Engl. J. Med. 342, 390-397. doi: 10.1056/NEJM200002103420604

Kyne, L., Warny, M., Qamar, A., and Kelly, C. P. (2001). Association between antibody response to toxin $\mathrm{A}$ and protection against recurrent Clostridium difficile diarrhoea. Lancet 357, 189-193. doi: 10.1016/S0140-6736(00)03 592-3

Larson, H. E., Barclay, F. E., Honour, P., and Hill, I. D. (1982). Epidemiology of Clostridium difficile in infants. J. Infect. Dis. 146, 727-733. doi: 10.1093/infdis/ 146.6.727

Lawley, T. D., Clare, S., Walker, A. W., Stares, M. D., Connor, T. R., Raisen, C., et al. (2012). Targeted restoration of the intestinal microbiota with a simple, defined bacteriotherapy resolves relapsing Clostridium difficile disease in mice. PLoS Pathog. 8:e1002995. doi: 10.1371/journal.ppat.1002995

Leekha, S., Aronhalt, K. C., Sloan, L. M., Patel, R., and Orenstein, R. (2013). Asymptomatic Clostridium difficile colonization in a tertiary care hospital: admission prevalence and risk factors. Am. J. Infect. Control 41, 390-393. doi: 10.1016/j.ajic.2012.09.023

Lessa, F. C., Winston, L. G., and McDonald, L. C. (2015). Burden of Clostridium difficile infection in the United States. N. Engl. J. Med. 372, 2369-2370. doi: 10.1056/NEJMc1505190

Ley, R. E., Peterson, D. A., and Gordon, J. I. (2006). Ecological and evolutionary forces shaping microbial diversity in the human intestine. Cell 124, 837-848. doi: 10.1016/j.cell.2006.02.017

Lo Vecchio, A., and Zacur, G. M. (2012). Clostridium difficile infection: an update on epidemiology, risk factors, and therapeutic options. Curr. Opin. Gastroenterol. 28, 1-9. doi: 10.1097/MOG.0b013e32834bc9a9

Longtin, Y., Paquet-Bolduc, B., Gilca, R., Garenc, C., Fortin, E., Longtin, J., et al. (2016). Effect of detecting and isolating Clostridium difficile carriers 
at hospital admission on the incidence of $C$. difficile infections: a quasiexperimental controlled study. JAMA Intern. Med. 176, 796-804. doi: 10.1001/ jamainternmed.2016.0177

Loo, V. G., Bourgault, A.-M., Poirier, L., Lamothe, F., Michaud, S., Turgeon, N., et al. (2011). Host and pathogen factors for Clostridium difficile infection and colonization. N. Engl. J. Med. 365, 1693-1703. doi: 10.1056/NEJMoa10 12413

Loo, V. G., Poirier, L., Miller, M. A., Oughton, M., Libman, M. D., Michaud, S., et al. (2005). A predominantly clonal multi-institutional outbreak of Clostridium difficile-associated diarrhea with high morbidity and mortality. N. Engl. J. Med. 353, 2442-2449. doi: 10.1056/NEJMoa051639

Louie, T. J., Miller, M. A., Mullane, K. M., Weiss, K., Lentnek, A., Golan, Y., et al. (2011). Fidaxomicin versus vancomycin for Clostridium difficile infection. N. Engl. J. Med. 364, 422-431. doi: 10.1056/NEJMoa0910812

Lyerly, D. M., Saum, K. E., MacDonald, D. K., and Wilkins, T. D. (1985). Effects of Clostridium difficile toxins given intragastrically to animals. Infect. Immun. 47, 349-352.

Lyras, D., O'Connor, J. R., Howarth, P. M., Sambol, S. P., Carter, G. P., Phumoonna, T., et al. (2009). Toxin B is essential for virulence of Clostridium difficile. Nature 458, 1176-1179. doi: 10.1038/nature07822

Manges, A. R., Labbe, A., Loo, V. G., Atherton, J. K., Behr, M. A., Masson, L., et al. (2010). Comparative metagenomic study of alterations to the intestinal microbiota and risk of nosocomial Clostridium difficile-associated disease. J. Infect. Dis. 202, 1877-1884. doi: 10.1086/657319

Marciniak, C., Chen, D., Stein, A. C., and Semik, P. E. (2006). Prevalence of Clostridium difficile colonization at admission to rehabilitation. Arch. Phys. Med. Rehabil. 87, 1086-1090. doi: 10.1016/j.apmr.2006.03.020

Mariat, D., Firmesse, O., Levenez, F., Guimarães, V., Sokol, H., Doré, J., et al. (2009). The Firmicutes/Bacteroidetes ratio of the human microbiota changes with age. BMC Microbiol. 9:123. doi: 10.1186/1471-2180-9-123

Matamoros, S., Gras-Leguen, C., Le Vacon, F., Potel, G., and de La Cochetiere, M.F. (2013). Development of intestinal microbiota in infants and its impact on health. Trends Microbiol. 21, 167-173. doi: 10.1016/j.tim.2012.12.001

Maziade, P.-J., Pereira, P., and Goldstein, E. J. C. (2015). A decade of experience in primary prevention of Clostridium difficile infection at a community hospital using the probiotic combination Lactobacillus acidophilus CL1285, Lactobacillus casei LBC80R, and Lactobacillus rhamnosus CLR2 (Bio-K+). Clin. Infect. Dis. 60(Suppl. 2), S144-S147. doi: 10.1093/cid/civ178

McCusker, M. E., Harris, A. D., Perencevich, E., and Roghmann, M.-C. (2003). Fluoroquinolone use and Clostridium difficile-associated diarrhea. Emerg. Infect. Dis. 9, 730-733. doi: 10.3201/eid0906.020385

McDonald, L. C., Owings, M., and Jernigan, D. B. (2006). Clostridium difficile infection in patients discharged from US short-stay hospitals, 1996-2003. Emerg. Infect. Dis. 12, 409-415. doi: 10.3201/eid1205.051064

McFarland, L. V., Beneda, H. W., Clarridge, J. E., and Raugi, G. J. (2007a). Implications of the changing face of Clostridium difficile disease for health care practitioners. Am. J. Infect. Control 35, 237-253. doi: 10.1016/j.ajic.2006.06.004

McFarland, L. V., Clarridge, J. E., Beneda, H. W., and Raugi, G. J. (2007b). Fluoroquinolone use and risk factors for Clostridium difficile-associated disease within a Veterans Administration health care system. Clin. Infect. Dis. 45, 1141-1151. doi: 10.1086/522187

McFarland, L. V., Elmer, G. W., Stamm, W. E., and Mulligan, M. E. (1991). Correlation of immunoblot type, enterotoxin production, and cytotoxin production with clinical manifestations of Clostridium difficile infection in a cohort of hospitalized patients. Infect. Immun. 59, 2456-2462.

McFarland, L. V., Mulligan, M. E., Kwok, R. Y., and Stamm, W. E. (1989). Nosocomial acquisition of Clostridium difficile infection. N. Engl. J. Med. 320, 204-210. doi: 10.1056/NEJM198901263200402

McFarland, L. V., Ozen, M., Dinleyici, E. C., and Goh, S. (2016). Comparison of pediatric and adult antibiotic-associated diarrhea and Clostridium difficile infections. World J. Gastroenterol. 22, 3078-3104. doi: 10.3748/wjg.v22.i11. 3078

Merrigan, M. M., Sambol, S. P., Johnson, S., and Gerding, D. N. (2003). Prevention of fatal Clostridium difficile-associated disease during continuous administration of clindamycin in hamsters. J. Infect. Dis. 188, 1922-1927. doi: $10.1086 / 379836$

Merrigan, M. M., Sambol, S. P., Johnson, S., and Gerding, D. N. (2009). New approach to the management of Clostridium difficile infection: colonisation with non-toxigenic $C$. difficile during daily ampicillin or ceftriaxone administration. Int. J. Antimicrob. Agents 33(Suppl. 1), S46-S50. doi: 10.1016/S0924-8579(09) 70017-2

Meyer, G. K. A., Neetz, A., Brandes, G., Tsikas, D., Butterfield, J. H., Just, I., et al. (2007). Clostridium difficile toxins A and B directly stimulate human mast cells. Infect. Immun. 75, 3868-3876. doi: 10.1128/IAI.00195-07

Miller, M., Gravel, D., Mulvey, M., Taylor, G., Boyd, D., Simor, A., et al. (2010). Health care-associated Clostridium difficile infection in Canada: patient age and infecting strain type are highly predictive of severe outcome and mortality. Clin. Infect. Dis. 50, 194-201. doi: 10.1086/649213

Moore, P., Kyne, L., Martin, A., and Solomon, K. (2013). Germination efficiency of clinical Clostridium difficile spores and correlation with ribotype, disease severity and therapy failure. J. Med. Microbiol. 62, 1405-1413. doi: 10.1099/ jmm.0.056614-0

Morris, J. G., Jarvis, W. R., Nunez-Montiel, O. L., Towns, M. L., Thompson, F. S., Dowell, V. R., et al. (1984). Clostridium difficile. Colonization and toxin production in a cohort of patients with malignant hematologic disorders. Arch. Intern. Med. 144, 967-969. doi: 10.1001/archinte.1984.003501701 09020

Muegge, B. D., Kuczynski, J., Knights, D., Clemente, J. C., González, A., Fontana, L., et al. (2011). Diet drives convergence in gut microbiome functions across mammalian phylogeny and within humans. Science 332, 970-974. doi: 10.1126/ science. 1198719

Muto, C. A., Pokrywka, M., Shutt, K., Mendelsohn, A. B., Nouri, K., Posey, K., et al. (2005). A large outbreak of Clostridium difficile-associated disease with an unexpected proportion of deaths and colectomies at a teaching hospital following increased fluoroquinolone use. Infect. Control Hosp. Epidemiol. 26, 273-280. doi: 10.1086/502539

Naaber, P., Lehto, E., Salminen, S., and Mikelsaar, M. (1996). Inhibition of adhesion of Clostridium difficile to Caco-2 cells. FEMS Immunol. Med. Microbiol. 14, 205-209. doi: 10.1111/j.1574-695X.1996.tb00288.x

Nakamura, S., Mikawa, M., Nakashio, S., Takabatake, M., Okado, I., Yamakawa, K., et al. (1981). Isolation of Clostridium difficile from the feces and the antibody in sera of young and elderly adults. Microbiol. Immunol. 25, 345-351. doi: 10.1111/j.1348-0421.1981.tb00036.x

Nelson, D. E., Auerbach, S. B., Baltch, A. L., Desjardin, E., Beck-Sague, C., Rheal, C., et al. (1994). Epidemic Clostridium difficile-associated diarrhea: role of secondand third-generation cephalosporins. Infect. Control Hosp. Epidemiol. 15, 8894. doi: $10.2307 / 30145537$

Novack, L., Kogan, S., Gimpelevich, L., Howell, M., Borer, A., Kelly, C. P., et al. (2014). Acid suppression therapy does not predispose to Clostridium difficile infection: the case of the potential bias. PLoS One 9:e110790. doi: 10.1371/ journal.pone. 0110790

Nylund, C. M., Goudie, A., Garza, J. M., Fairbrother, G., and Cohen, M. B. (2011). Clostridium difficile infection in hospitalized children in the United States. Arch. Pediatr. Adolesc. Med. 165, 451-457. doi: 10.1001/archpediatrics.201 0.282

Ogra, P. L. (2010). Ageing and its possible impact on mucosal immune responses. Ageing Res. Rev. 9, 101-106. doi: 10.1016/j.arr.2009.07.007

Ozaki, E., Kato, H., Kita, H., Karasawa, T., Maegawa, T., Koino, Y., et al. (2004). Clostridium difficile colonization in healthy adults: transient colonization and correlation with enterococcal colonization. J. Med. Microbiol. 53, 167-172. doi: $10.1099 / \mathrm{jmm} .0 .05376-0$

Pakpour, S., Bhanvadia, A., Zhu, R., Amarnani, A., Gibbons, S. M., Gurry, T., et al. (2017). Identifying predictive features of Clostridium difficile infection recurrence before, during, and after primary antibiotic treatment. Microbiome 5:148. doi: 10.1186/s40168-017-0368-1

Peach, S. L., Borriello, S. P., Gaya, H., Barclay, F. E., and Welch, A. R. (1986). Asymptomatic carriage of Clostridium difficile in patients with cystic fibrosis. J. Clin. Pathol. 39, 1013-1018. doi: 10.1136/jcp.39.9.1013

Pépin, J., Valiquette, L., and Cossette, B. (2005). Mortality attributable to nosocomial Clostridium difficile-associated disease during an epidemic caused by a hypervirulent strain in Quebec. CMAJ 173, 1037-1042. doi: 10.1503/cmaj. 050978

Peterfreund, G. L., Vandivier, L. E., Sinha, R., Marozsan, A. J., Olson, W. C., Zhu, J., et al. (2012). Succession in the gut microbiome following antibiotic and antibody therapies for Clostridium difficile. PLoS One 7:e46966. doi: 10.1371/ journal.pone.0046966 
Pirs, T., Ocepek, M., and Rupnik, M. (2008). Isolation of Clostridium difficile from food animals in Slovenia. J. Med. Microbiol. 57, 790-792. doi: 10.1099/jmm.0. 47669-0

Pochapin, M. (2000). The effect of probiotics on Clostridium difficile diarrhea. Am. J. Gastroenterol. 95, S11-S13. doi: 10.1016/S0002-9270(99)00809-6

Pruitt, R. N., and Lacy, D. B. (2012). Toward a structural understanding of Clostridium difficile toxins A and B. Front. Cell. Infect. Microbiol. 2:28. doi: $10.3389 /$ fcimb.2012.00028

Rajilić-Stojanović, M., Heilig, H. G. H. J., Molenaar, D., Kajander, K., Surakka, A., Smidt, H., et al. (2009). Development and application of the human intestinal tract chip, a phylogenetic microarray: analysis of universally conserved phylotypes in the abundant microbiota of young and elderly adults. Environ. Microbiol. 11, 1736-1751. doi: 10.1111/j.1462-2920.2009.01900.x

Rea, M. C., Clayton, E., O'Connor, P. M., Shanahan, F., Kiely, B., Ross, R. P., et al. (2007). Antimicrobial activity of lacticin 3,147 against clinical Clostridium difficile strains. J. Med. Microbiol. 56, 940-946. doi: 10.1099/jmm.0.47085-0

Rea, M. C., O'Sullivan, O., Shanahan, F., O'Toole, P. W., Stanton, C., Ross, R. P., et al. (2012). Clostridium difficile carriage in elderly subjects and associated changes in the intestinal microbiota. J. Clin. Microbiol. 50, 867-875. doi: 10. 1128/JCM.05176-11

Reeves, A. E., Koenigsknecht, M. J., Bergin, I. L., and Young, V. B. (2012). Suppression of Clostridium difficile in the gastrointestinal tracts of germfree mice inoculated with a murine isolate from the family Lachnospiraceae. Infect. Immun. 80, 3786-3794. doi: 10.1128/IAI.00647-12

Reeves, A. E., Theriot, C. M., Bergin, I. L., Huffnagle, G. B., Schloss, P. D., and Young, V. B. (2011). The interplay between microbiome dynamics and pathogen dynamics in a murine model of Clostridium difficile infection. Gut Microbes 2, 145-158. doi: 10.4161/gmic.2.3.16333

Reichardt, C., Chaberny, I. F., Kola, A., Mattner, F., Vonberg, R. P., and Gastmeier, P. (2007). Dramatischer Anstieg von Clostridium-difficileassoziierter Diarrhoe in Deutschland: Ist der neue Stamm PCR-Ribotyp 027 bereits angekommen? Dtsch. Med. Wochenschr. 132, 223-228. doi: 10.1055/s2007-959314

Richardson, S. A., Alcock, P. A., and Gray, J. (1983). Clostridium difficile and its toxin in healthy neonates. Br. Med. J. (Clin. Res. Ed) 287:878. doi: 10.1136/bmj. 287.6396.878

Riggs, M. M., Sethi, A. K., Zabarsky, T. F., Eckstein, E. C., Jump, R. L. P., and Donskey, C. J. (2007). Asymptomatic carriers are a potential source for transmission of epidemic and nonepidemic Clostridium difficile strains among long-term care facility residents. Clin. Infect. Dis. 45, 992-998. doi: 10.1086/ 521854

Ringel, Y., and Maharshak, N. (2013). Intestinal microbiota and immune function in the pathogenesis of irritable bowel syndrome. Am. J. Physiol. Gastrointest. Liver Physiol. 305, G529-G541. doi: 10.1152/ajpgi.00207.2012

Robinson, C. J., and Young, V. B. (2010). Antibiotic administration alters the community structure of the gastrointestinal micobiota. Gut Microbes 1, 279284. doi: 10.4161/gmic.1.4.12614

Rodriguez-Palacios, A., Reid-Smith, R. J., Staempfli, H. R., Daignault, D., Janecko, N., Avery, B. P., et al. (2009). Possible seasonality of Clostridium difficile in retail meat, Canada. Emerg. Infect. Dis. 15, 802-805. doi: 10.3201/eid1505. 081084

Rodriguez-Palacios, A., Staempfli, H. R., Duffield, T., and Weese, J. S. (2007). Clostridium difficile in retail ground meat, Canada. Emerg. Infect. Dis. 13, 485-487. doi: 10.3201/eid1303.060988

Rolfe, R. D., and Song, W. (1995). Immunoglobulin and non-immunoglobulin components of human milk inhibit Clostridium difficile toxin A-receptor binding. J. Med. Microbiol. 42, 10-19. doi: 10.1099/0022261542-1-10

Rousseau, C., Poilane, I., Pontual, L., de Maherault, A.-C., Le Monnier, A., and Collignon, A. (2012). Clostridium difficile carriage in healthy infants in the community: a potential reservoir for pathogenic strains. Clin. Infect. Dis. 55, 1209-1215. doi: 10.1093/cid/cis637

Rupnik, M., Wilcox, M. H., and Gerding, D. N. (2009). Clostridium difficile infection: new developments in epidemiology and pathogenesis. Nat. Rev. Microbiol. 7, 526-536. doi: 10.1038/nrmicro2164

Sambol, S. P., Merrigan, M. M., Tang, J. K., Johnson, S., and Gerding, D. N. (2002). Colonization for the prevention of Clostridium difficile disease in hamsters. J. Infect. Dis. 186, 1781-1789. doi: 10.1086/345676
Samore, M. H., DeGirolami, P. C., Tlucko, A., Lichtenberg, D. A., Melvin, Z. A., and Karchmer, A. W. (1994). Clostridium difficile colonization and diarrhea at a tertiary care hospital. Clin. Infect. Dis. 18, 181-187. doi: 10.1093/clinids/18. 2.181

Sarker, M. R., and Paredes-Sabja, D. (2012). Molecular basis of early stages of Clostridium difficile infection: germination and colonization. Future Microbiol. 7, 933-943. doi: 10.2217/fmb.12.64

Schirmer, J., and Aktories, K. (2004). Large clostridial cytotoxins: cellular biology of Rho/Ras-glucosylating toxins. Biochim. Biophys. Acta 1673, 66-74. doi: 10.1016/j.bbagen.2004.03.014

Schultsz, C., van den Berg, F. M., Kate, F. W., ten Tytgat, G. N., and Dankert, J. (1999). The intestinal mucus layer from patients with inflammatory bowel disease harbors high numbers of bacteria compared with controls. Gastroenterology 117, 1089-1097. doi: 10.1016/S0016-5085(99)70 393-8

Schwartz, K. L., Darwish, I., Richardson, S. E., Mulvey, M. R., and Thampi, N. (2014). Severe clinical outcome is uncommon in Clostridium difficile infection in children: a retrospective cohort study. BMC Pediatr. 14:28. doi: 10.1186/ 1471-2431-14-28

Sekirov, I., Russell, S. L., Antunes, L. C. M., and Finlay, B. B. (2010). Gut microbiota in health and disease. Physiol. Rev. 90, 859-904. doi: 10.1152/physrev.00045. 2009

Shen, A. (2012). Clostridium difficile toxins: mediators of inflammation. J. Innate Immun. 4, 149-158. doi: 10.1159/000332946

Shen, N. T., Maw, A., Tmanova, L. L., Pino, A., Ancy, K., Crawford, C. V., et al. (2017). Timely use of probiotics in hospitalized adults prevents Clostridium difficile infection: a systematic review with meta-regression analysis. Gastroenterology 152, 1889.e9-1900.e9. doi: 10.1053/j.gastro.2017.0 2.003

Shim, J. K., Johnson, S., Samore, M. H., Bliss, D. Z., and Gerding, D. N. (1998). Primary symptomless colonisation by Clostridium difficile and decreased risk of subsequent diarrhoea. Lancet 351, 633-636. doi: 10.1016/S0140-6736(97) 08062-8

Simor, A. E., Bradley, S. F., Strausbaugh, L. J., Crossley, K., and Nicolle, L. E. (2002). Clostridium difficile in long-term-care facilities for the elderly. Infect. Control Hosp. Epidemiol. 23, 696-703. doi: 10.1086/501997

Songer, J. G., Jones, R., Anderson, M. A., Barbara, A. J., Post, K. W., and Trinh, H. T. (2007). Prevention of porcine Clostridium difficile-associated disease by competitive exclusion with nontoxigenic organisms. Vet. Microbiol. 124, 358-361. doi: 10.1016/j.vetmic.2007.04.019

Sorg, J. A., and Sonenshein, A. L. (2008). Bile salts and glycine as cogerminants for Clostridium difficile spores. J. Bacteriol. 190, 2505-2512. doi: 10.1128/JB. 01765-07

Spigaglia, P. (2016). Recent advances in the understanding of antibiotic resistance in Clostridium difficile infection. Ther. Adv. Infect. Dis. 3, 23-42. doi: 10.1177/ 2049936115622891

Stark, P. L., and Lee, A. (1982). Clostridia isolated from the feces of infants during the first year of life. J. Pediatr. 100, 362-365. doi: 10.1016/S0022-3476(82) 80430-7

Steele, J., Mukherjee, J., Parry, N., and Tzipori, S. (2013). Antibody against TcdB, but not TcdA, prevents development of gastrointestinal and systemic Clostridium difficile disease. J. Infect. Dis. 207, 323-330. doi: 10.1093/infdis/ jis669

Stevens, V., Dumyati, G., Fine, L. S., Fisher, S. G., and van Wijngaarden, E. (2011). Cumulative antibiotic exposures over time and the risk of Clostridium difficile infection. Clin. Infect. Dis. 53, 42-48. doi: 10.1093/cid/cir301

Sullivan, A., Edlund, C., and Nord, C. E. (2001). Effect of antimicrobial agents on the ecological balance of human microflora. Lancet Infect. Dis. 1, 101-114. doi: 10.1016/S1473-3099(01)00066-4

Tattevin, P., Buffet-Bataillon, S., Donnio, P.-Y., Revest, M., and Michelet, C. (2013). Clostridium difficile infections: do we know the real dimensions of the problem? Int. J. Antimicrob. Agents 42(Suppl.), S36-S40. doi: 10.1016/j.ijantimicag.2013. 04.009

Tedesco, F. J., Barton, R. W., and Alpers, D. H. (1974). Clindamycin-associated colitis. A prospective study. Ann. Intern. Med. 81, 429-433. doi: 10.7326/00034819-81-4-429

Terveer, E. M., Crobach, M. J. T., Sanders, I. M. J. G., Vos, M. C., Verduin, C. M., and Kuijper, E. J. (2017). Detection of Clostridium difficile in feces of 
asymptomatic patients admitted to the hospital. J. Clin. Microbiol. 55, 403-411. doi: 10.1128/JCM.01858-16

Theriot, C. M., Koenigsknecht, M. J., Carlson, P. E., Hatton, G. E., Nelson, A. M., Li, B., et al. (2014). Antibiotic-induced shifts in the mouse gut microbiome and metabolome increase susceptibility to Clostridium difficile infection. Nat. Commun. 5:3114. doi: 10.1038/ncomms4114

Thompson, C. M., Gilligan, P. H., Fisher, M. C., and Long, S. S. (1983). Clostridium difficile cytotoxin in a pediatric population. Am. J. Dis. Child. 137, 271-274. doi: 10.1001/archpedi.1983.02140290057015

Trzasko, A., Leeds, J. A., Praestgaard, J., Lamarche, M. J., and McKenney, D. (2012). Efficacy of LFF571 in a hamster model of Clostridium difficile infection. Antimicrob. Agents Chemother. 56, 4459-4462. doi: 10.1128/AAC.063 $55-11$

van Dorp, S. M., Smajlovic, E., Knetsch, C. W., Notermans, D. W., de Greeff, S. C., and Kuijper, E. J. (2017). Clinical and microbiological characteristics of Clostridium difficile infection among hospitalized children in the Netherlands. Clin. Infect. Dis. 64, 192-198. doi: 10.1093/cid/ciw699

van Nood, E., Vrieze, A., Nieuwdorp, M., Fuentes, S., Zoetendal, E. G., and de Vos, W. M., et al. (2013). Duodenal infusion of donor feces for recurrent Clostridium difficile. N. Engl. J. Med. 368, 407-415. doi: 10.1056/NEJMoa1205037

Vardakas, K. Z., Polyzos, K. A., Patouni, K., Rafailidis, P. I., Samonis, G., and Falagas, M. E. (2012). Treatment failure and recurrence of Clostridium difficile infection following treatment with vancomycin or metronidazole: a systematic review of the evidence. Int. J. Antimicrob. Agents 40, 1-8. doi: 10.1016/j. ijantimicag.2012.01.004

Vernaya, M., McAdam, J., and Hampton, M. D. (2017). Effectiveness of probiotics in reducing the incidence of Clostridium difficile-associated diarrhea in elderly patients: a systematic review. JBI Database System. Rev. Implement. Rep. 15, 140-164. doi: 10.11124/JBISRIR-2016-003234

Vincent, C., Miller, M. A., Edens, T. J., Mehrotra, S., Dewar, K., and Manges, A. R. (2016). Bloom and bust: intestinal microbiota dynamics in response to hospital exposures and Clostridium difficile colonization or infection. Microbiome 4:12. doi: 10.1186/s40168-016-0156-3

Vincent, C., Stephens, D. A., Loo, V. G., Edens, T. J., Behr, M. A., Dewar, K., et al. (2013). Reductions in intestinal Clostridiales precede the development of nosocomial Clostridium difficile infection. Microbiome 1:18. doi: 10.1186/20492618-1-18

Viscidi, R., Willey, S., and Bartlett, J. G. (1981). Isolation rates and toxigenic potential of Clostridium difficile isolates from various patient populations. Gastroenterology 81, 5-9.

Voth, D. E., and Ballard, J. D. (2005). Clostridium difficile toxins: mechanism of action and role in disease. Clin. Microbiol. Rev. 18, 247-263. doi: 10.1128/CMR. 18.2.247-263.2005

Warny, M., Pepin, J., Fang, A., Killgore, G., Thompson, A., Brazier, J., et al. (2005). Toxin production by an emerging strain of Clostridium difficile associated with outbreaks of severe disease in North America and Europe. Lancet 366, 1079-1084. doi: 10.1016/S0140-6736(05)67420-X

Weese, J. S. (2010). Clostridium difficile in food-innocent bystander or serious threat? Clin. Microbiol. Infect. 16, 3-10. doi: 10.1111/j.1469-0691.2009.03108.x

Welkon, C. J., Long, S. S., Thompson, C. M., and Gilligan, P. H. (1985). Clostridium difficile in patients with cystic fibrosis. Am. J. Dis. Child. 139, 805-808. doi: 10.1001/archpedi.1985.02140100067032

Werner, H., and Kuntsche, J. (2000). Infektionen im Alter-was ist anders? Z. Gerontol. Geriatr. 33, 350-356. doi: 10.1007/s003910070031

Wilcox, M. H., Gerding, D. N., Poxton, I. R., Kelly, C., Nathan, R., Birch, T., et al. (2017). Bezlotoxumab for Prevention of Recurrent Clostridium difficile Infection. N. Engl. J. Med. 376, 305-317. doi: 10.1056/NEJMoa1602615
Wilson, K. H. (1983). Efficiency of various bile salt preparations for stimulation of Clostridium difficile spore germination. J. Clin. Microbiol. 18, 1017-1019.

Wilson, K. H., and Perini, F. (1988). Role of competition for nutrients in suppression of Clostridium difficile by the colonic microflora. Infect. Immun. $56,2610-2614$.

Wilson, K. H., Silva, J., and Fekety, F. R. (1981). Suppression of Clostridium difficile by normal hamster cecal flora and prevention of antibiotic-associated cecitis. Infect. Immun. 34, 626-628.

Winston, J. A., Thanissery, R., Montgomery, S. A., and Theriot, C. M. (2016). Cefoperazone-treated mouse model of clinically-relevant Clostridium difficile strain R20291. J. Vis. Exp. 118:e54850. doi: 10.3791/54850

Wongwanich, S., Pongpech, P., Dhiraputra, C., Huttayananont, S., and Sawanpanyalert, P. (2001). Characteristics of Clostridium difficile strains isolated from asymptomatic individuals and from diarrheal patients. Clin. Microbiol. Infect. 7, 438-441. doi: 10.1046/j.1198-743x.2001. 00308.x

Woodmansey, E. J. (2007). Intestinal bacteria and ageing. J. Appl. Microbiol. 102, 1178-1186. doi: 10.1111/j.1365-2672.2007.03400.x

Wu, G. D., Chen, J., Hoffmann, C., Bittinger, K., Chen, Y.-Y., Keilbaugh, S. A., et al. (2011). Linking long-term dietary patterns with gut microbial enterotypes. Science 334, 105-108. doi: 10.1126/science.120 8344

Wullt, M., Hagslätt, M.-L. J., and Odenholt, I. (2003). Lactobacillus plantarum 299v for the treatment of recurrent Clostridium difficile-associated diarrhoea: a double-blind, placebo-controlled trial. Scand. J. Infect. Dis. 35, 365-367. doi: $10.1080 / 00365540310010985$

Yaeger, M. J., Kinyon, J. M., and Glenn Songer, J. (2007). A prospective, case control study evaluating the association between Clostridium difficile toxins in the colon of neonatal swine and gross and microscopic lesions. J. Vet. Diagn. Invest. 19, 52-59. doi: 10.1177/104063870701900108

Yatsunenko, T., Rey, F. E., Manary, M. J., Trehan, I., Dominguez-Bello, M. G., Contreras, M., et al. (2012). Human gut microbiome viewed across age and geography. Nature 486, 222-227. doi: 10.1038/nature 11053

Zacharioudakis, I. M., Zervou, F. N., Pliakos, E. E., Ziakas, P. D., and Mylonakis, E. (2015). Colonization with toxinogenic C. difficile upon hospital admission, and risk of infection: a systematic review and meta-analysis. Am. J. Gastroenterol. 110, 381-390; quiz 391. doi: 10.1038/ajg.2015.22

Zilberberg, M. D., Shorr, A. F., and Kollef, M. H. (2008). Increase in Clostridium difficile-related hospitalizations among infants in the United States, 20002005. Pediatr. Infect. Dis. J. 27, 1111-1113. doi: 10.1097/INF.0b013e31817 eef13

Zupancic, M. L., Cantarel, B. L., Liu, Z., Drabek, E. F., Ryan, K. A., Cirimotich, S., et al. (2012). Analysis of the gut microbiota in the old order Amish and its relation to the metabolic syndrome. PLoS One 7:e43052. doi: 10.1371/journal. pone. 0043052

Conflict of Interest Statement: The authors declare that the research was conducted in the absence of any commercial or financial relationships that could be construed as a potential conflict of interest.

Copyright $\odot 2018$ Schäfler and Breitrück. This is an open-access article distributed under the terms of the Creative Commons Attribution License (CC BY). The use, distribution or reproduction in other forums is permitted, provided the original author(s) and the copyright owner are credited and that the original publication in this journal is cited, in accordance with accepted academic practice. No use, distribution or reproduction is permitted which does not comply with these terms. 